\title{
Kajian Terhadap Kebijakan Pembangunan Infrakstruktur Jl. Gajahmada Mataram Dengan Metode Analityc Hierarchy Proses
}

Agus Partono dan Titik Wahyuningsih

Program Studi Teknik Sipil Universitas Muhammadiyah Mataram partono.agus@gmail.com

\section{INFO ARTIKEL}

\section{Riwayat Artikel:}

Diterima:8-12-2016

Disetujui:1 1-02-2017

\section{Kata Kunci:}

Kebijakan Infrstruktur Jalan

Hirarki

AHP

\section{A. LATAR BELAKANG}

Pembangunan infrastruktur Mataram sepanjang 4,60 KM yang dilaksanakan tahun 2013 baru saja selesai, pembangunan infrastuktur jalan tersebut sekarang ini sudah kelihatan manfaatnya yaitu arus lalu lintas mejadi lancar, kanan dan kiri jalan bermunculan tempat usaha baru dan sudah terasa suasana di lingkungan sekitrar proyek menjadi ramai baik siang maupun malam.
ABSTRAK

\begin{abstract}
Abstrak:Pembangunan infakstruktur Jalan Gajahmada Mataram yang baru saja selesai dilaksanakan, telah dirasakan manfaantnya, namun juga menimbulkan pro dan kontra karena kebijakan yang menetapkan desain elevasi permukaan jalan dan jembatan menjadi lebih tinggi mulai 50 CM sampai 3 meter dari kondisi semula.Dengan metode analytic hierarchy proses penentuan kebijakan tersebut dianalisis dan dinialai dari 8 kriteria yang lazim dipergunakan yaitu kriteria teknis (3), non teknis (4) dan biaya biaya (1). Penilaian melalui kuisioner oleh responden yang berasal dari tokoh masyarakat sekitar, pimpinan dari dinas PU (Bina Marga), para dosen pengampu bidang jalan raya, pimpinan asosiasi HPJI dan tenaga ahli konsultan yang sering merencanakan jalan. Hasil analisis perbandingan seluruh kriteria yang ditinjau diperoleh bahwa desain elevasi permukaan jalan tinggi lebih unggul dibanding dengan desain elevasi permukaan jalan rendah, hal ini ditunjukan dari hasil pembobotan untuk desain elevasi tinggi mencapai bobot sebesar $(0,574)$, sementara bobot untuk desain elevasi rendah sebesar $(0,426)$.
\end{abstract}

\begin{abstract}
The construction of the Gajahmada Mataram Road infrastructure, which has just been completed, has been felt to be beneficial, but it also raises pros and cons because the policy that sets the design of road surface and bridge elevation is higher from 50 CM to 3 meters from the original condition. With the analytic hierarchy method, the process of determining the policy is analyzed and analyzed from the 8 commonly used criteria, namely technical criteria (3), non-technical (4) and cost costs (1). Assessment through questionnaires by respondents from surrounding community leaders, leaders from the Public Works Agency (Bina Marga), highway supervisors, leaders of the HPJl association and expert consultants who often plan roads. The results of the comparison analysis of all the criteria reviewed obtained that the design of high road surface elevation is superior compared to the design of low road surface elevation, this is shown from the weighting for the high elevation design reaching a weight of (0.574), while the weight for the design elevation is (0.426)
\end{abstract}

Namun disamping banyak manfaat didapat, kebijakan pembangunan infastruktur jalan dengan desain elevasi lebih tinggi dari kondisi semula yaitu ditinggikan antara 50 CM sampai dengan 3 meter khususnya pada perlintasan sungai (jembatan), tak ayal menimbulkan pro dan kontra dikalangan para ahli mapun orang-orang yang terkena dampak langsung akibat proyek tersebut. 
Oleh karena itu apakah kebijakan apakah kebijakan yang telah diambil dalam hal pembangunan infrastruktur Jalan Gajahmada dengan pendekatan/metode AHP(Analyic Hierarchy Process). Diharapkan melalui penelitan ini dapat di buktikan metode AHP yang banyak digunakan dalam pengambilan keputusan di bidang manajemen, cukup handal pula diterapkan dalam bidang teknik dan rekayasa sehingga dapat membantu para pengambil kebijakan dalam proses pengambilan keputusan yang obyektif terutama di lingkungan pemerintah. Metode AHP memberikan suatu cara atau pola bahwa setiap keputusan diambil didasarkan atas kriteria yang teruji misalnya daya tahan kontruksi, kendalan sistem serta dari segi penilian kualitatif berupa perbandingan tingkat kenyamanan, dampak lingkungan/sosial, ketersediaan bahan dan lain-lain.

Untuk mendapatkan hasil sesuai hasil harapan dan tujuan I, respon exspert yang dituju harus benar-benar memiliki kemampuan/keahlian di bidangnya dan tingkat konsistensi terhadap jawaban yang disampaikan, apabila tidak konsisten maka hasilnya tidak sesuai yang diharapkan.

\section{B. METODE PENELITIAN}

Penelitian ini menggunakan metode $A H P$ yang bertujuan memberikan penilaian terhadap kriteriakriteria yang mempengaruhi kebijakan dalam pembangunan infrastruktur Jalan Gajahmada.

Penelitian ini berfokus pada perumusan suatu model berbasis AHP untuk menilai kebijakan yang telah diterapkan dalam pembangunan infrastruktur Jalan Gajahmada dengan desain elevasi permukaan jalan yangditinggikan atau desain elevasi permukaan jalan seperti kondisi semula.

Sesuai struktur hirarhki yang sudah dibentuk pada gambar 3.2 diatas, terlihat kriteria-kriteria dan alternatif pilihan, sebagai tujuan adalah pemilihan alternatif desain yang dipilih, sedangkan level II menunjukan kriteria-kriteria yang menjadi pertimbangan dalam pemilihan, dapat dijelaskan sebagai berikut:

\section{Kriteria teknis, ada 3 faktor yaitu:}

a. Daya tahan terhadap Genangan dan Banjir.

Daya tahan terhadap Genangan air hujan (pada jalan) dan Banjir sungai (pada jembatan) suatu desain elevasi jalan dan jembatan dalam mengantisipasi dirinya dari gangguan akibat genangan air hujan yang sering terjadi dan dikeluhkan oleh masyarakat penguna jalan maupun gangguan akibat adanya banjir sungai (pada jembatan) yang diperhitungkan untuk mengantisipasi adanya banjir, dari data dampak banjir yang dikeluarkan dari Balai Wilayah Sungai (BWS) Nusa Tenggara I, debit banjir rancangan untuk $\mathrm{Q}_{10 t h}=$ $234,34 \mathrm{~m}^{3} / \mathrm{dtk}$ dan $_{25 \text { th }}=251,83 \mathrm{~m}^{3} / \mathrm{dtk}$ dengan bentang jembatan $20 \mathrm{~m}$ dan kedalaman sungai $5 \mathrm{~m}$ dengan tinggi jagaan 1,2 m, maka kemungkinan air banjir sudah membahayakan jembatan.

\section{b. Daya tahan terhadap Beban Lalulintas}

Daya tahan terhadap Beban Lalulintas suatu desain elevasi jalan dan jembatan merupakan suatu ukuran yang menunjukan kemampuan dari desain elevasi jalan dan jembatan dalam mengantisifasi dirinya dari kerusakan akibat adanya beban lalulintas (kendaraan) yang akan melewati jalan dan jembatan tersebut, seperti diketahui Jl. Gajahmada akan mengalami perubahan status dari jalan Provinsi menjadi jalan Nasional sehingga kelas jalan dari kelas II (beban gandar 8,2 ton) menjadi kelas I (beban gandar 12 ton) sedangakan untuk jembatan terdapat perubahan standar beban jembatan dari BM 70 menjadi BM 100.

c. Daya tahan terhadap Perkembangan Lalulintas

Daya tahan terhadap Perkembangan Lalulintas suatu desain elevasi jalan dan jembatan merupakan suatu ukuran yang menunjukan kemampuan dari desain elevasi jalan dan jembatan dalam mengantisipasi dirinya terhadap perkembangan lalulintas akibat peningkatan fungsi jalan dari fungsi semula hanya sebagai jalan kolektor yaitu jalan dari perukiman menuju pusat kota tempat bekerja bertambah fungsi menjadi jalan arteri yaitu jalan yang menghubungkan antar provinsi, jika semula kendaraan dari Lembar dan Praya yang ke Mataram masuk melewati jalan TGH. Lopan Cakranegara namun saat ini kendaraan lebih suka melewati Jalan Gajahmada.

\section{Kriteria Non Teknis, Ada 4 Faktor Yaitu: \\ a. Kenyamanan Pengguna Jalan}

Kenyamanan merupakan ukuran performa yang langsung dirasakan oleh pengguna jalan, kenyamanan umumnya berkaitan permukaan jalan yang rata, mulus dan datar, dalam penilaian ini selain kenyamanan setelah jalan beroperasi juga kenyamanan pengguna jalan selama pembangunan perlu ditanyakan kepada responden karena selama pembangunan jalan tidak ditutup semua atau diahlihkan ke jalan lain melainkan pengguna jalan masih dapat melewati jalan tersebut.

\section{b. Jangka Waktu Pelaksanaan Pembangunan}

Jangka waktu pelaksanaan adalah waktu yang digunakan untuk menyelesaikan konstruksi dimana waktu pelaksanaan konstruksi merupakan kriteria yang menjadi pertimbangan baik pengambil kebijakan maupun pengguna jalan, makin cepat selesai makin bernilai baik meskipun dari segi mutu dan biaya berbanding terbalik.

\section{c. Kelancaran Arus Lalulintas}

Kelancaran arus lalulintas adalah ukuran performa jalan dalam melayani penguna jalan tanpa hambatan yang berarti, tinjauan arus lalulintas bukan hanya setelah selesai pembangunan tetapi juga selama masa konstruksi. 


\section{d. Dampak Sosial dan Lingkungan}

Dampak sosial dan terhadap lingkungan adalah efek yang terjadi karena adanya pembangunan infastruktur jalan baik selama pembangunan maupun setelah jalan beroperasi, dampak rumah/ruko yang harus menyusaikan tinggi lantai rumahnya, banyak saluran air dari rumah/ruko yang tidak dapat mengalir karena saluran pembuang lebih tinggi, bising dan polusi akibat beroprasinya alat berat, akan tetapi ada juga hal yang positif yaitu harga tanah melonjak tinggi, membuka peluang orang usaha dsb.

\section{3. kriteria biaya, ada satu faktor yaitu:}

\section{a. Biaya Pembangunan Jalan dan Jembatan}

Biaya pembangunan jalan dan jembatan ini dibandingkan antara biaya pembangunan untuk desain elevasi permukaan jalan. Tinggi seperti kondisi setelah jadi dan desain elevasi permukaan jalan rendah (seperti semula).

Untuk lebih jelasnya dapat dilihat pada Gambar

1

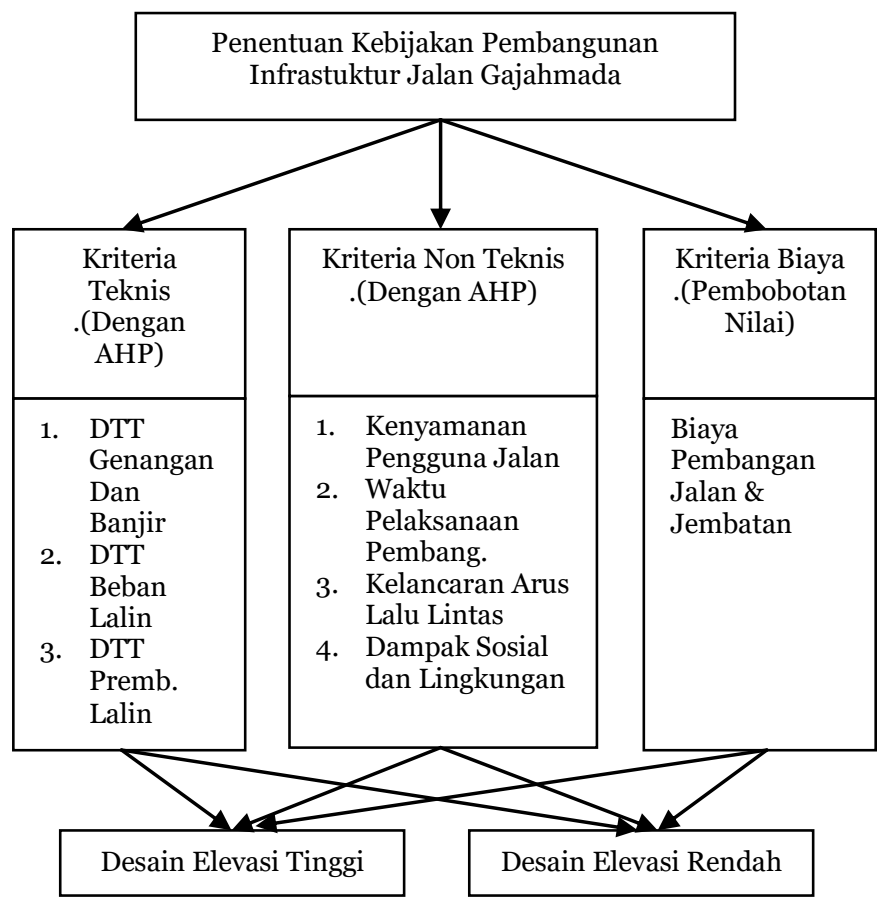

Gambar 1. Bagan desain penelitian

\section{HASIL DAN PEMBAHASAN}

\section{Faktor Teknis yang Paling Berpengaruh}

Hasil pembobotan faktor teknis menunjukan bahwa diantara ketiga faktor teknis yang ada, faktor yang dianggap paling dominan untuk mengukur keandalan Desain Elevasi Jalan dan Jembatan diantara Desain yang dibuat Tinggi dan Desain yang tetap Rendah adalah faktor daya tahan terhadap Perkembangan Lalulintas $(0,375)$, Faktor kedua adalah daya tahan terhadap Beban Lalulintas $(0,365)$ dan yang terakhir daya tahan terhadap Genangan dan Banjir (o,260).
Hasil ini mengisyaratkan bahwa responden melihat daya tahan terhadap Perkembangan Lalulintas Lebih Penting terhadap faktor yang lain meskipun selisih beda pendapat masih terbilang tidak signifikan.

Tabel 1

Hasil Bobot untuk faktor teknis

\begin{tabular}{clc}
\hline No & \multicolumn{1}{c}{ Faktor } & Bobot \\
\hline 1 & $\begin{array}{l}\text { Daya tahan terhadap perkembangan } \\
\text { lalulintas. }\end{array}$ & $\mathbf{0 , 3 7 5}$ \\
2 & $\begin{array}{l}\text { Daya tahan terhadap beban } \\
\text { lalulintas. }\end{array}$ & $\mathbf{0 , 3 6 5}$ \\
3 & $\begin{array}{l}\text { Daya tahan terhadap Genagan dan } \\
\text { Banjir. }\end{array}$ & $\mathbf{0 , 2 6 0}$ \\
\hline
\end{tabular}

Sumber: Analsis Peneliti

\section{Faktor Non Teknis yang Paling Berpengaruh}

Sementara itu, untuk faktor non teknis yang paling berpengaruh untuk menilai keandalan Desain Elevasi Jalan dan Jembatan ditempati oleh faktor Kelancaran Arus Lalulintas $(0,315)$, yang kedua adalah faktor Kenyamanan Pengguna Jalan (0,307), yang arus ketiga faktor adalah faktor Dampak Sosial dan Lingkungan $(0,217)$ dan yang terakhir adalah faktor Waktu Pelaksanaan Pembangunan $(0,110)$ hal ini menunjukan bahwa responden menghendaki arus lalulintas tetap lancar dalam kondisi apapun (dalam masa pembangunan mapun pasca pembangunan) tanpa menutup atau atau mengalihkan arus lalulintas, karena jika ditutup atau diahlikan maka waktu tempuh ked an dari kantor akan lebih lama.

\section{Tabel 2}

Bobot untuk faktor non teknis

\begin{tabular}{clc}
\hline No & \multicolumn{1}{c}{ Faktor } & Bobot \\
\hline 1 & Kelancaran arus lalulintas & $\mathbf{0 , 3 1 5}$ \\
2 & Kenyamanan pengguna jalan & $\mathbf{0 , 3 0 7}$ \\
3 & Dampak Sosial dan Lingkungan & $\mathbf{0 , 2 1 7}$ \\
4 & Waktu Pelaksanaan Pembangunan & $\mathbf{0 , 1 1 0}$ \\
\hline \multicolumn{2}{c}{ Sumber: Analsis Peneliti }
\end{tabular}

\section{Keandalan Desain Elevasi Berdasarkan Faktor Teknis dan Non Teknis}

Setelah menilai faktor-faktor apa yang paling berpengaruh, selanjutnya yang penting dinilai seberapa jauh faktor-faktor tersebut menentukan pilihan Desain Elevasi Permukaan Jalan dan Jembatan.

Penilian keandalan Desain Elevasi berdasarkan gabungan antara faktor teknis, non teknis dan biaya. Hasil penilaian tiap faktor dapat ditelusuri berdasarkan pembobotan sebagaimana terkandung dalam vektor VKI sampai VK7 dan dirangkum dalam Tabel 3 dibawah ini.

Tabel 3

Hasil bobot untuk semua faktor

\begin{tabular}{clccc}
\hline \multirow{2}{*}{ No } & \multicolumn{1}{c}{ Faktor } & \multicolumn{2}{c}{ Bobot Desain Elevasi } & \multirow{2}{*}{ Rasio } \\
\cline { 2 - 4 } & \multicolumn{2}{c}{ Tinggi } & Rendah & \\
\hline 1 & $\begin{array}{l}\text { DTT Genagan dan } \\
\text { Banjir }\end{array}$ & 0,763 & 0,237 & $3,2: 1$ \\
2 & $\begin{array}{l}\text { DTT Beban } \\
\text { Lalulintas }\end{array}$ & 0,735 & 0,265 & $2,8: 1$ \\
3 & $\begin{array}{l}\text { DTT Perkembangan } \\
\text { Lalulintas }\end{array}$ & 0,750 & 0,250 & $3,0: 1$ \\
4 & $\begin{array}{l}\text { Kenyamanan } \\
\text { Pengguna Jalan }\end{array}$ & 0,205 & 0,795 & $1: 3,9$ \\
\hline
\end{tabular}




\begin{tabular}{|c|c|c|c|c|}
\hline 5 & $\begin{array}{l}\text { Waktu Pelaksanaan } \\
\text { Pembangunan }\end{array}$ & 0,188 & 0,812 & $1: 4,3$ \\
\hline 6 & $\begin{array}{l}\text { Kelancaran Arus } \\
\text { Lalulintas }\end{array}$ & 0,804 & 0,196 & $4,1: 1$ \\
\hline 7 & $\begin{array}{l}\text { Dampak Sosial dan } \\
\text { Lingkungan }\end{array}$ & 0,257 & 0,743 & $1: 2,9$ \\
\hline 8 & Biaya Pembangunan & 0,446 & 0,554 & 1: 1,2 \\
\hline
\end{tabular}

\section{Hasil Penilian Akhir}

Penilian akhir dari hasil analisis dapat ditelusuri dari pembobotan sebagaimana tercantum dalam vektor VA21 atau yang ditampilkan dalam Tabel 4 berikut:

Tabel 4

Hasil Vektor eigen untuk penilian keandalan

\begin{tabular}{ccc}
\multicolumn{3}{c}{ Desain Elevasi Jalan } \\
\hline No & \multicolumn{1}{c}{ Desain Elevasi Jalan } & Bobot \\
\hline 1 & Desain Elevasi Tinggi & 0,574 \\
2 & Desain Elevasi Rendah & 0,426 \\
\hline \multicolumn{2}{c}{ Sumber: Analsis Peneliti }
\end{tabular}

Dari tabel terlihat bahwa Desain Elevasi Jalan dan Jembatan yang dibuat tinggi secara keseluruhan lebih unggul dibanding Desain Elevasi Jalan dan Jembatan yang tetap Rendah seperti ditunjukan oleh nilai eigen untuk Desain Elevasi Tinggi dengan bobot sebesar $(\mathbf{0}, \mathbf{5 7 4})$ lebih tinggi dibanding nilai eigen untuk Desain Elevasi Rendah dengan bobot sebesar (o,426). Akhirnya dapat disimpulkan bahwa pemilihan Desain Elevasi Tinggi yang dilaksanakan oleh pemerintah dalam hal ini Dinas PU Provinsi NTB, Satuan Kerja P2JN Provinsi NTB memang dapat dipertangungjawabkan secara ilmiah.

\section{E. Kesimpulan dan Saran \\ 1. Kesimpulan}

Dari analisis yang telah dilakukan, dapat ditarik beberapa poin kesimpulan sebagai berikut:

a. Bahwa berdasarkan analisis $A H P$, diketahui faktor teknis yang mempunyai bobot tertinggi adalah faktor daya tahan terhadap Perkembangan Lalulintas $(0,375)$. Ini mengindikasikan bahwa Perkembangan Lalulintas sangat dipentingkan oleh responden mengingat Kota Mataram sebagai ibukota Provinsi akan mengalami perkembangan (terutama lalulintasnya) yang sangat pesat mengingat Jalan Gajahmada akan ditingkatkan statusnya menjadi Jalan Nasional sebagai jalan utama yang menghubungkan antar kota antar provinsi melalui Pelabuhan Lembar-Padang Bai.

b. Bahwa berdasarkan analisis $A H P$, faktor non teknis yang mempunyai bobot tertinggi adalah kelancaran Arus Lalulintas (0,364). Ini mengindikasikan bahwa faktor kelancaran lalu lintas merupakan faktor non teknis yang paling dipertimbangkan dalam pembangunan jalan berdasarkan penilaian responden.

c. Dari 8 faktor, Desain Elevasi Jalan dan Jembatan yang dibuat Tinggi unggul pada 4 faktor yaitu daya tahan terhadap Genangan dan Banjir, daya tahan terhadap daya Beban Lalulintas, daya tahan terhadap Perkembangan Lalu Lintas dan Kelancaran Arus Lalulintas, sedangkan Desain Elevasi Rendah juga unggul pada 4 faktor yaitu Kenyamanan Pengguna Jalan, Waktu Pelaksanaan Pembangunan, Dampak Sosial dan Lingkungan dari Faktor Biaya yang lebih murah.

d. Dari analisis perbandingan yang melibatkan seluruh faktor yang ditinjau diketahui bahwa Desain Elevasi Jalan dan Jembatan yang dibuat tinggi rata-rata lebih unggul dibandingkan dengan Desain Elevasi Jalan dan Jembatan tetap rendah. Hal ini ditunjukan dari hasil pembobotan untu Desain Elevasi Tinggi mencapai $(0,574)$, sementara bobot untuk Desain Elevasi yang tetap Rendah sebesar (0, 426).

\section{Saran}

Dari analisis dan kesimpulan yang ada, selanjutnya dapat diberikan saran atau rekomendasi sebagai berikut:

a. Pembangunan infrastruktur Jalan Gajahmada Mataram yang sudah selesai perlu didukung meskipun banyak terjadi kontroversi pada saat pelaksanaan pembangunannya.

b. Sebelum pembangunan infrastruktur sebaiknya pemerintah melakukan studi dengan metode $A H P$ dan mensosialisasikan pada masyarakat melalui media Koran dan atau langsung kepada masyarakat sekitar agar tidak menimbulkan gejolak pada saat pelaksanaan pembangunan.

\section{DAFTAR RUJUKAN}

[1] Kumar \& Ganesh, (1996b). An empirical analysis of the use of the AHP for estimating membershif values in a fuzzy sets and system.

[2] Saaty, T.L., (1994), Decision Making for Leaders The Analytic Hierarchy Prosess for decisions in a complex world, Pittsburgh: Univ. of Pittsburgh.

[3] Saaty, T.L., (2000), Fudamentals of Decision Making and priority theory. 2nd ed. Pittsburgh, PA: RWS Publications.

[4] Sarhan, A. Z., (2011), Application Of Analytic Hierarchy Prosess (AHP) in The Evaluation and Selection of an Information System Reengineering Projects. 